\title{
COMUNICAÇÃO
}

\section{ABSENCE OF CROSS-REACTIVITY BETWEEN DENGUE AND HUMAN IMMUNODEFICIENCY VIRUS TYPE 1 (HIV-1)}

\section{H.L. Guerra', M.F.F. Lima Costa 3 \\ U.H.M. Paullno2, F.A. Prolett $\beta$, C.M.F. Antunes ${ }^{3}$ and M.D.C. Gulmarąe日 3}

An association between malaria, schistosomiasis and tropical splenomegaly and human immunodeficiency virus type 1 (HIV-1) seropositivity has been observed in Africa ${ }^{12}$. Recently, the cross-reactivity between infection with Schistosoma mansoni and HIV-1 seropositivity was not confirmed in Brazil ${ }^{5}$. The potential cros-reactivity among other endemic of epidemic diseases in developing countries and HIV-1 has not been investigated as of yet. We studied the possible cross-reactivity between dengue (break bone fever) and HIV-1.

In December, 1986 there were 3000 cases of dengue and 10 cases of Acquired Immunodeficiency Syndrome (AIDS) in Ceará State in Northeast of Brazil $^{34}$. We analyzed sera of 89 individuals with dengue in this State (46 males and 43 females; mean age $=32 \pm 16$ years). All sera were tested by ELISA (Salk Dupont Laboratories) and all of them were negative for HIV-1 antibodies in at least two of three examinations. This result demonstrates that there was no cross-reactivity between dengue and HIV-1 in the investigated Brazilian patients.

\section{REFERENCES}

1. Biggar RJ, Johnson BK, Oster C, Sarin PS, Ocheng D, Tukei P, Nsanze H, Alexander S, Bodner AJ, Siongok TA, Gallo RC, Blattner WA. Regional variation in prevalence of antibody against Human T-lymphotropic virus types $I$ and III in Kenya, East Africa. International Journal of Cancer 35: 763-767, 1985.

2. Biggar RJ, Melbye M, Sarin PS, Gigase PL, Kestens L, Bodner AJ, Demedts P, Stevens WJ, Paluku L, Delacollette C, Blattner WA. ELISA HTLV retrovirus antibodies reactivity associated with malaria and immune complexes in healthy Africans. The Lancet II: 520-523, 1985.

3. Brasil. Ministério da Saúde. Divisão de Dermatologia Sanitária. Distribuição dos casos notificados de AIDS no Brasil. Brasilia. 3p (mimeo). Dezembro, 1986.

4. Brasil. Ministério da Saúde. Superintendência de Campanhas de Saúde Pública, Diretoria Regional do Ceará. Fortaleza, 1 p (mimeo). Dezembro, 1986.

5. Costa MFFL, Proietti FA, Paulino UHM, Antunes CMF, Guimarães MDC, Rocha RS \& Katz N. Absence of cross-reactivity between Schistosoma mansoni infection and human immunodeficiency virus (HIV). Transactions of the Royal Society of Tropical Medicine and Hygiene 82:262, 1988.

1. Superintendência de Campanhas de Saúde Pública (SUCAM), Ministério da Saúde, Brasil.

2. Laboratório, Pós-Graduaçāo em Medicina Tropical, Universidade Federal de Minas Gerais.

3. Grupo Interdepartamental de Pesquisas em Epidemiologia, Universidade Federal de Minas Gerais. Caixa Postal: 360, Belo Horizonte, Minas Gerais, Brasil.

Recebido para publicaçāo em 22/6/87. 